\title{
The University of Newcastle, New South Wales
}

\section{Keri Glastonbury}

\section{Critical Animals}

Find a city

Find myself a city to live in. David Byrne, 'Cities'

This article is an experiment in mixing personal and professional trajectories and tells a few dislocated stories about my experience of moving from Sydney to Newcastle to teach creative writing. Sometimes I'm writing as a first home buyer, at other points as an early career academic, still thinking through areas that might lead to future research (ideally with a local focus). In particular, my involvement with Newcastle's This Is Not Art (TINA) festival has inspired me to explore ways to better integrate the extra-literary into tertiary creative writing pedagogy. These are preliminary thoughts, however, as I begin to sift through my recent transitions, confronting in the process many complex ambivalences and possible new alliances.

In 2005, a year before I came to know the Sydney to Newcastle stretch of freeway more intimately, I headed north to Newcastle for the annual TINA festival - an amorphous program of arts and media events held on the October long weekend. Some highlights that year included 'Subterranean Sex', a panel on DIY pornography and a video I saw of a ghost haunting a jogger along the coastal cliffs of Coogee, also my 'spiritual home' at the time. The irony of that trip is that I remember speculating - as you do when you go to a place you haven't spent any, or much, time in - whether or not Newcastle would be a place I could live. Not being able to afford a house in Sydney and, in true Kate Crawford Adult Themes-style trying to reconcile this with my Generation X maturation process, I was open to beta-testing new environments. I wasn't quite ready to follow the advice to flee town, meted out to 'those who have not already reached their middle years' by Reserve Bank governor Ian Macfarlane (Crawford 2006: 148), but Newcastle piqued my interest mildly. It seemed there were cheaper houses, a good health food store, enormous old ocean baths and historic buildings left in the city. There was a certain wabi sabi (a Japanese aesthetic perhaps badly translated as 'elegant poverty') to the inner city areas inland from the coastal suburbs, which in post-industrial Newcastle are more habitable following the closure of the major steel works in 1999 (meaning they are no longer cloaked in black coal dust and phosphates aren't burning holes in pyjamas hanging out on clothes lines).

I'm sure many of the Generation Y TINA audience (those in their twenties) who also came up from Sydney and Melbourne, or down from Brisbane, went through a similar process: noting the cheap rent, the pubs and beaches, while it still being a university town. As short-term visitors we engaged in a kind of 
amateur ethnography, taking digital photos for Flickr sites and vicariously checking out the local scene. But by the end of the long weekend, 'devil you know' decisions were being affirmed and, like Kate Crawford, I'd decided that cosmopolitan Sydney was for me. As Crawford argues, there are other ways of rethinking the measures of adulthood than owning houses: renting doesn't necessarily preclude a 'poetics of space' or notion of home (in Bachelard's terms). Eastern suburbs art deco apartments R Us, as I yet again reconciled choosing to live in an area where I could not come close to affording a mortgage.

Five months later and I find out that I have an academic job at Newcastle University as a Lecturer in Creative Writing, and in one year I've gone from being a TINA tourist to sitting at the table at the Octapod as a Director of TINA's creative research symposium, Critical Animals. Critical Animals pitches itself to honours and postgraduate students (as well as those recently graduated and still at a loose end), early career academics, quasi-intellectuals and anyone else interested in devouring critical contexts for the kinds of experimental and emerging arts and media practices in the TINA program. The Pod, the local community organisation behind TINA, began as an acronym for Platypuses of Deliverance and there were eight of them who pooled their dole checks to start it all off over a decade ago. This Is Not Art is named after a once-prominent piece of Newcastle graffiti, now disappeared under a coat of paint. From Magritte's 'This is not a pipe' to PiL's 'This is not a love song', this kind of naming strategy implies a via negativa, even an ancient way of gesturing to the divine as the unutterable in discourse: God is not this, not that... As a symposium on creative research, Critical Animals picks up on the distinction between art and critique. What is not art, in terms of what is critique? Where does one start and the other begin? Ideally everyone should be both artful and critical about their practices - be it politics, academic research, writing, living.

After nine months commuting between Sydney and Newcastle (there's only so many times you can mark the halfway point by the dinosaur at the Australian reptile park) I finally swan into town and buy my first house - a tiny onebedroom miner's cottage with a permaculture garden in Tighes Hill. Years of living in apartments with only a few pot plants to my name are redressed as I quickly amass books on organic gardening. I refer to it as the 'Bogan Bronx' to my friends, and although Tighes Hill might look a bit like the mythic workingclass Balmain of yore for the purposes of real estate hyperbole (or even Tuscany, if you squint at the rooftops and church spires over Islington Park) the suburb isn't gentrified. There's not a sourdough bread shop for miles, although a few Tibetan peace flags flapping in the wind signify the odd hippy household. It's got a sleepy mix of welfare families, Sudanese refugees, lesbian mums, pensioners off to Keno at the social club, kids in billycarts careering down the street - and now me, upcountry in my dungarees, tending to my basil and mint. I am one of the lucky ones who has secured an academic appointment in the sweet-here-after of a Doctorate of Creative Arts (DCA). Though you never get quite what you wish for: I've landed $160 \mathrm{kms}$ north of 'perfect', doing what is becoming the equivalent of 'country service' for early career academics.

Newcastle has a rugged beauty (for all its ecological blight). The coal ships haunt the horizon like ghost ships, spectres of the Industrial Revolution someone forgot to come and tow off stage. Behind my house the coal trains move so slowly under the overpass it's tempting to jump on top and escape to some unknown place (likely China or Taiwan). It all seems so last century, but of course it is totally pertinent to the future. Environmentally, this could be the site of the death of the next century. Acclimatising to my new surroundings, physically and socially, is both enlivening and confronting. Newcastle has to 
become my 'triggering town', as Richard Hugo argues : 'The poem is always in your home town, but you have a better chance of finding it in another' (Hugo 1979: 12). I'm not a local (not yet, not ever?). They say everyone is racist on some level. Perhaps I'm regionalist. I silently shout at people going about their lives: 'You think this is adequate?' A friend, taking me on one of my earliest tours to get my bearings, showed me the boys with their hotted up Toranas (and Barinas!) parked at the foreshore. Seemed like hundreds of them, with a few chicks in the backseats. Perhaps this is not art? This is the regional youth culture de rigueur. Stockton lies across the harbour. Leigh-Leigh land.

\section{$* * *$}

In his recent essay 'Transistor', ex-Novacastrian Mark Mordue writes about his pride in his hometown and working-class roots, beginning with a memory of listening to Double $\mathrm{J}$ on his grandfather's radio. This narrative is familiar to me from the stories I hear from my students, of growing up in large families squashed into miners' cottages in Wallsend or weatherboard homes on the shores of Lake Macquarie, and being the first in the family to go to university. Newcastle has a strong working-class Labor history, though I'm sure many students are now also coming from Liberal-voting 'aspirational' families stretching down the Central Coast. Like Mark Mordue, I also grew up in a regional town, which I left for the big smoke of Sydney (I even had a radio show on the local community station - renowned for playing the Velvet Underground's Heroin during the drive-time slot). I am writing this story in reverse now, however, moving to a regional city after 18 years in the metropolis. While I can tell you that I'm well aware theoretically that the socalled 'cosmopolitan' is merely a different form of 'parochialism' - one blinded by a superiority complex - I can also tell you that there's no Chinatown in Newcastle (instead I eat at the petite bourgeois restaurants that line Darby Street) and that local pride can sometimes spill over into a smug suspicion of the outside world. I haven't moved far, but I feel the self-imposed exile on many levels - while also enjoying the slower pace (riding my bike along the foreshore past pelicans, tiny tug boats and the hulking coal loader). My girlfriend, who was too young for a 'suburban seachange', didn't move with me to Newcastle and instead went overseas. Last week I found myself at 'Mixed Froots', the kind of gay and lesbian social event I would have shunned in Sydney, and as the waitress was clearing away my glass she said positively, 'I think it's great that you all get together like this'.

Sometimes I also feel mildly displaced in the TINA scene, especially as I'm now officially part of the 'establishment'. The alternative ethos remains compelling to me, however, as growing up in Wagga Wagga this is how I survived as an adolescent, eventually differentiating myself from those lapping the main street. Yet there's a paradox. I want to claim that regional cities make things happen that seem impossible in Sydney and other urban centres. Away from cultural epicentres, so the logic goes, you have to make your own culture. Even at a civic level, the arts are being embraced by post-industrial cities making themselves over as 'creative cities', and Newcastle City Council might have in mind places like Manchester in the UK (with the added lifestyle bonus of sunny weather). There is already, as is often the case in cities with high youth unemployment, a strong local history of urban subculture in Newcastle. The Loft youth centre offers holiday classes including hip hop (breakdancing, aerosol art, beats and rhymes, dj-ing etc), podcasting, zine-making, skate clinics and video production for posting on YouTube. TINA is another shining exemplar of DIY culture, as Kate Crawford writes:

Every September, hundreds of writers, new media artists, activists, musicians and interested observers make their way to 
Newcastle in New South Wales. When they get there they become part of the largest fringe festival event in Australia, called This Is Not Art, or TINA. (Crawford 2006: 214)

Yet the converse is also true. The regions hold on to their traditions. Think CWA. Think WEA. Think the Classics Department at Newcastle University. When I ask a Director of Earthling, TINA's environmental festival - who I find out is a postgraduate student in English at Newcastle University - if she wants to do a paper for Critical Animals, I assume she's working on something like Eco-criticism. Turns out she's doing a PhD on Ezra Pound.

Another motivation for becoming involved in Critical Animals was that I often find honours students' projects more interesting than senior academics' ARC grants (and feel more inspired by next-generation thinkers and writers). For example, as part of Critical Animals a group of UTS honours students installed a nineteenth-century Parisian arcade built from cardboard, inspired by the work of Walter Benjamin. With my bias towards contemporary applications of knowledge, what does it mean for me to be an early career academic in a traditional arts department where the majority are Oxbridge-educated? If creative arts students (let alone early career academics) aren't coming to their degrees with a rigorous grounding in traditional orthodoxies or canons, they are, however, discovering things about the intellectual/creative tradition while at university. The current trend towards vocational degrees hasn't entirely killed off interest in more philosophical enquiry. The so-called 'ahistorical' generations are heuristically discovering rich resonances with, and contexts for, their creative work while in the ivory tower.

$* * *$

It's hard not to see people in terms of physiognomy pamphlets, sometimes. You expect a room full of creative arts postgraduates at TINA to look a certain way: the art school glasses, the awkward nerdiness of a techy young VJ, the comely zine wench in her op shop dress. We live in a post-Professor Judith 'Jack' Halberstom world, the gender theorist and Professor of English at University of Southern California, who in her staff photo on the faculty website crouches in denim jeans, a black t-shirt and butch buzz cut, her biceps covered in sailor jerry. But Critical Animals isn't about the 'cool kids' of academia in any sort of exclusive way. While it may appear as if I've gravitated towards a once a year gathering of ring-ins from out of town, it is the local community that generated and continues to spawn TINA - in a way which again makes regional areas perfect sites for these kinds of events, capable of pulling a particular energy and focus. Critical Animals was also, for me, a moment of synthesis between University heterotopias and the wellspring of their broader creative communities; just as hearing University of Newcastle students on the panels with those from elsewhere cathected my past and present.

The divide between the Birmingham School cultural studies academics and the members of the subcultures they studied - punks, mods etc - is less of an issue in creative arts degrees, where you are assumed to be a 'maker' of culture yourself. This issue was raised by early career academic Dr Anna Poletti (Australia's first doctor of zines and founder of Critical Animals) in her paper on 'doubt'. Anna gave the example of academics who first of all question why, as middle-class elites, they are studying straight-edged punks, global hip-hop or whatever, then go on to repeat standard sociological research paradigms as if this moment of self-questioning were just something to gloss over at the beginning. Perhaps embracing and interrogating that gap further might threaten their reason for being? Are they denying other voices a go? 
While Anna is speaking I have a doubt-moment of my own. What does it mean for me as a newly minted creative writing lecturer seriously to confront the issue that creative writing students are being encouraged to produce literary product for a market that doesn't 'really' exist? And to take this on fully; not to baulk at the point at which this logical endgame seems to do away with my job. The answer may lie in the fact that traditional literary publishing opportunities are not necessarily the sole litmus test for student outcomes and success. As creative writing teachers we must remain engaged not only with the teaching of craft skills but also the changing cultures of writing. The mass of students doing creative writing postgraduate degrees still consider themselves to be writers (even though only a rare few will ever receive a publishing advance).

My interest in this is as an academic/writer (and, god forbid, a poet), and also as a reader who craves some deterritorialisation and reterritorialisation of literary genres. We work with students on their collections of poems, short stories and novels, acting as though there's still a literary market out there when, more realistically, except for those writing popular genre fiction or lucky enough to win The Vogel (the 'bread' award), the kinds of writing communities students are likely to be part of are much smaller, DIY and unprofessional or amateur. This is where TINA (with both Critical Animals and The National Young Writers Festival as part of its umbrella) becomes particularly pertinent. What of cultures of writing that aren't necessarily literary, or that depart from the literary? Where do they sit in the academy? How are ideas of authorship exploding beyond the current narrow and commercialised definitions of the writer? Again, the context of TINA reminds me that this goes beyond the literary - all artists who come to TINA tend to be interested in the wide range of the contemporary art, politics and culture on offer. There might not be a 'market' there in the same way there is at the Sydney Writers' Festival, but there most definitely is a productive matrix.

Each generation continues to find avenues to express its avant-garde, even if these moments are never canonised, or flare only briefly. There are many young writers, for example, who aren't touched by the oft-touted 'decline' of literary publishing, as it's always been out of their ambit. What matters instead is the forming of nodal communities of readers and writers, and the crossfertilisation of their myriad literacies. Supporting this in terms of traditional publishing may require a different economic paradigm (smaller print runs to the right audience?). As someone from Generation X, inhabiting a kind of rainshadow between Boomer and ' $Y$ ', I at least experienced the mini publishing phenomenon of 'grunge literature' in the early 90s. Although short, sweet and highly derided, there are still authors from the period, like Andrew McGahan and Christos Tsolkias, who continue to write conceptually innovative literary fiction that I identify as being part of my 'era'. Similarly, I had an overwhelming sense of generational alliance reading Kate Crawford's Adult Themes: Rewriting the Rules of Adulthood, a basic, but oh-so-necessary, media deconstruction in the voice of someone directly relating to her research area. When looking around the room at Critical Animals I was acutely aware that I have received a foot up that others will continue to have to clamour for. I'd very recently been in their shoes, surviving for a long time as a casual academic 'gleaner'. And with my new job (with at least three-year contract security) have come some of the 'adult' rites of passage that I had all but given up on.

\section{List of works cited}

Bachelard, Gaston 1994 Poetics of Space, Boston: Beacon Press return to text

Byrne, David 1979 'Cities', in Fear of Music, Talking Heads. Warner Bros/WEA return to text 
Crawford, Kate 2006 Adult Themes: Rewriting the Rules of Adulthood, Sydney: Macmillan return to text

Hugo, Richard 1979 The Triggering Town: Lectures and Essays on Poetry and Writing, New York: WW Norton and Company return to text

Lydon/Levine/Atkins 1984 'This Is Not A Love Song', This Is What You Want... This Is What You Get, PiL [Public Image Ltd]. Virgin Records return to text

Mordue, Mark 2006 'Transistor', HEAT 12, November, 121-27 return to text

Dr Keri Glastonbury is a Lecturer in Creative Writing at the University of Newcastle, Australia. She completed a DCA at the University of Technology, Sydney in 2005. Her thesis, titled 'Shut up, nobody wants to hear your poems!', staged a friendly title bout between painter Adam Cullen and poet Ted Nielsen, two male grunge auteurs of her generation. An article taken from her thesis was published in Cultural Studies Review Volume 13, No 1 (March 2006). She has also published two books of poetry, Hygienic Lily (Five Islands Press, 1999) and super-regional (Vagabond, 2001) and has an unpublished manuscript 'Grit Salute' (2004). She has been the recipient of writer's grants from the Australia Council (including the B.R. Whiting Rome studio) and the NSW Ministry for the Arts. In 2006 she directed Critical Animals: creative research symposium as part of Newcastle's This Is Not Art (TINA) Festival. She is also an editor of the small publishing company, Local Consumption Publications (www.localconsumption.com) who are this year releasing the title Strawberry Hills Forever by Vanessa Berry.

\section{TEXT}

Vol 11 No 1 April 2007

http://www.griffith.edu.au/school/art/text/

Editors: Nigel Krauth \& Jen Webb

Text@griffith.edu.au 